\title{
Chapter 1 \\ Introduction to True Bugs (Heteroptera) of the Neotropics
}

\author{
Antônio R. Panizzi and Jocélia Grazia
}

\begin{abstract}
True bugs (Heteroptera) are a diverse and complex group of insects, particularly in the neotropics. The fauna of these bugs has been investigated through time, but our knowledge of the species living in the Neotropical Region is limited. In this introductory chapter, we give a general view on true bugs classification and biogeography, with concise comments on their general characteristics and bioecology of each major taxon that comprise each of the seven infraorders of Heteroptera.
\end{abstract}

\subsection{Introduction}

The true bugs (Heteroptera) constitute a very interesting widely distributed group of insects, which is greatly diversified in tropical zones. Considered the largest group of insects with incomplete metamorphosis, heteropterans have been studied on both basic and applied aspects worldwide.

Along the years, several books have been published on Heteroptera, the majority on specific aspects, such as certain groups (taxa) of particular areas, and others on more general comprehensive issues. Of more broad interest, two books about the latter were published relatively recently. The first was dedicated to the classification and natural history of true bugs in particular, with insights on the history of the study of Heteroptera, how to collect and preserve true bugs, historical biogeogra-

\footnotetext{
A.R. Panizzi (凶)

Laboratório de Entomologia, Embrapa Trigo, Caixa Postal 3081, Passo Fundo, RS 99001-970, Brazil

e-mail: antonio.panizzi@embrapa.br

J. Grazia

Departamento de Zoologia, Instituto de Biociências, Universidade Federal do Rio Grande do Sul (UFRGS), Av. Bento Gonçalves 9500, prédio 43435, Bairro Agronomia, Porto Alegre, RS 91501-970, Brazil e-mail: jocelia@ufrgs.br
} 
phy, and comments of species of economic importance (Schuh and Slater 1995). The second book is a massive review of the world literature on species of economic importance, ranging from pest species of crops to species of medical importance (e.g., transmitters of Chagas disease) and to species that are of "nuisance" to humans (Schaefer and Panizzi 2000).

Considering the Neotropical Region, not a general book devoted to Heteroptera has been published in the last $70+$ years. There are texts dealing with Hemiptera (Heteroptera) such as the one by Costa Lima (1940) on the true bugs of Brazil and the one by Berg (1879) devoted to true bugs of Argentina. Recently, Grazia and Fernandes (2012) made an overview of the true bugs of Brazil, updating what was published before on many scattered publications.

In this introductory chapter, we give a concise and fast overview of the true bugs of the neotropics. This includes a general view on their classification and biogeography, with concise comments on their general characteristics and bioecology of each major taxon that comprise each of the seven infraorders of Heteroptera.

\subsection{Classification, Biogeography, General Characteristics, and Bioecology of Neotropical True Bugs}

The order Hemiptera, suborder Heteroptera, is divided into seven infraorders: Enicocephalomorpha, Dipsocoromorpha, Gerromorpha, Nepomorpha, Leptopodomorpha, Cimicomorpha, and Pentatomomorpha. These seven infraorders were recognized by Schuh (1979) based on the information on the evolutionary tendencies of heteropterans mouthparts and feeding habits described by Cobben (1978). Recently, Weirauch and Schuh (2011) revised the actual knowledge on the systematics and evolution of the heteropterans.

\subsubsection{Enicocephalomorpha}

This infraorder, the unique-headed bugs, is divided in two families, Aenictopecheidae and Enicocephalidae. The first family is subdivided into four subfamilies with ten genera and 20 species. These bugs live on or underneath the soil debris or under tree barks showing omnivorous feeding habits (Grazia and Fernandes 2012). The Enicocephalidae has 33 genera and over 400 species divided into five subfamilies. Members of this family show swarming behavior with sexual dimorphism, females being much bigger than males. Wygodzinsky and Schmidt (1991) presented a monography of the fauna of the New World. 


\subsubsection{Dipsocoromorpha}

This infraorder includes the smallest heteropterans with 47 genera and over 200 species, divided into five families, of which Ceratocombidae and Schizopteridae are better studied in the New World. The fauna in the neotropics is greatly diverse and poorly studied (Grazia and Fernandes 2012). Weirauch and Štys (2014) performed a phylogenetic analysis of this infraorder supporting its monophyly.

These small-sized heteropterans, very inconspicuous, live within fallen leaves, in natural small vegetation, or in tree canopy. They are hard to intercept, and many resemble small beetles.

\subsubsection{Gerromorpha}

Known as the semiaquatic bugs (water striders), the infraorder Gerromorpha comprises over 2,000 species in 11 families, with the majority of species in the neotropics belonging to the families Gerridae, Hebridae, Hydrometridae, Mesoveliidae, and Veliidae (Grazia and Fernandes 2012). The most comprehensive references for Gerromorpha, including morphology, phylogeny, biogeography, and keys for identification, were published by Andersen (1982). Great habitats dominated by freshwater, such as the Amazonia and the Pantanal in the neotropics of mostly Brazil, include a great number of species, many undescribed and waiting to be studied.

The Gerridae include bugs that live mostly on the water surface, with median and posterior legs elongated. Eight subfamilies are recognized (Andersen 1982), of which Trepobatinae contains a greater number of genera, at least in Brazil (Grazia and Fernandes 2012).

The Hebridae are small (1.3-3.7 mm) cryptic bugs living on herbaceous vegetation along waterways. Over 150 species are known and included in seven genera and two subfamilies (Hebrinae and Hyrcaninae) (Andersen 1981, 1982).

The Hydrometridae are long bugs $(2.7-22 \mathrm{~mm}$ ) found on vegetation or on rocks along the side of creeks and rivers. The over 100 species described are included in three subfamilies (Hydrometrinae, Heterocleptinae, and Limnobatodinae) (Andersen 1977).

The Mesoveliidae are small $(1.2-4.2 \mathrm{~mm})$, with variable wing development and shape. They live associated with floating vegetation or on open areas over the water. There are about 40 species included in two subfamilies (Mesoveliinae and Madeoveliinae). Very little is known about the Neotropical mesoveliids.

The Veliidae is a fairly large family (38 genera and about 600 species) (Andersen 1982). These bugs posses a truncated body, $1-10 \mathrm{~mm}$ long, well adapted to live on the water surface. There are six subfamilies (Ocelloveliinae, Rhagoveliinae, Perittopinae, Veliinae, Microveliinae, and Haloveliinae). They are easily found and captured and a well-studied group in many parts of the world, but not in the Neotropical Region. 


\subsubsection{Nepomorpha}

The Nepomorpha, or true water bugs, comprises about 2,000 species placed on 11 families. Their size varies from $1 \mathrm{~mm}$ (Pleidae and Helotrephidae) to $130 \mathrm{~mm}$ (Belostomatidae). They are, in general, predators, with some Corixidae feeding on algae and decaying vegetal matter. In the neotropics, Pereira et al. (2007) presented keys for family and genera identification of species occurring in the Central Amazon in Brazil. Species of the following families are found in the neotropics: Belostomatidae, Corixidae, Gelastocoridae, Naucoridae, Nepidae, Notonectidae, Ochteridae, Pleidae, and Potamocoridae. The most speciose families are Naucoridae; Belostomatidae, which include the giant water bugs, Lethocerus spp.; Nepidae; and Notonectidae (Grazia and Fernandes 2012).

\subsubsection{Leptopodomorpha}

About 400 species distributed in four families comprise the infraorder Leptopodomorpha, or shore bugs. The major reference to the literature and classification of the group is by Schuh et al. (1987). In the neotropics only Saldidae is represented. Usually ovoids, these dark fast-moving bugs are found in nearby water in humid open areas. They are predators, even able to dig in order to capture their preys (Grazia and Fernandes 2012).

\subsubsection{Cimicomorpha}

This infraorder is the largest infraorder of Heteroptera including about 20,000 species in 16 families (Schuh and Slater 1995). The Cimicomorpha is a well-studied infraorder, especially because of its economic and health importance. Of the 16 families referred to by Schuh and Štys (1991), the most common and important ones will be covered in this book.

\section{Minute Pirate Bugs (Anthocoridae)}

These small to minute flattened, dark, oval or elongated insects are predaceous, but may feed on pollen and other parts of plants. Schuh and Slater (1995) presented an overview of the family worldwide, presenting a key for the seven tribes, and Carpintero (2002) wrote the first catalog devoted to Neotropical species. Lattin (2000) reviewed the species that are known to occur in managed ecosystems. Apparently, they are important as biological control of pests in agroecosystems. In Brazil there are about 100 species described (Grazia and Fernandes 2012). 


\section{Plant Bugs (Miridae)}

This is, by far, the most diverse and speciose family within the Heteroptera, with about 1,300 genera and over 11,000 described species worldwide and over 500 genera and more than 3,000 species in the neotropics. In the neotropics, the majority of the species belong to the subfamilies Orthotylinae, Mirinae, and Deraeocorinae. The main taxonomic work for the Neotropical mirids was carried out by José C. M. Carvalho, who described about 400 genera and over 2,000 species and published the world catalog from 1957 to 1960 in a series of five publications (references in Chap. 10).

Mirids, known as plant bugs or capsids, are small- to medium-sized, elongated to ovoid bugs with triangular heads; they show variable coloration, being either phytophagous or carnivorous (predators).

The biology of mirids including habits and hosts has been published in several different publications and were synthesized by Wheeler (2000a, b, 2001). They are important pests in agricultural crops, and the predatory species show potential to be used in biological control programs. Among the most common species, we can cite those in the genera Lygus, Monalonion, Pseudatomoscelis, Tenthecoris, Microtechnites, and Pycnoderes as pests and Phytocoris, Blepharidopterus, Campylomma, Campyloneura, and Engytatus as potential predators.

\section{Damsel Bugs (Nabidae)}

The nabids, known as damsel bugs, are small- to medium-sized, elongated and robust bugs, with pale coloration. They are active predators, found in agricultural and urban areas. Schuh and Slater (1995) presented a key to the two subfamilies, Prostemmatinae and Nabinae. In the neotropics there are about 11 genera and 83 species described, with the genus Arachnocoris, Praecarthasis, Hoplistoscelis, Nabis, Alloeorhynchus, and Pagasa the most speciose (see Chap. 11). The majority of the literature refers to species of the Old World, and the New World fauna is treated by Harris $(1930,1931,1939)$ and Kerzhner (1986).

\section{Assassin Bugs (Reduviidae Excluding Triatominae)}

The so-called assassin bugs, the reduviids, are voracious terrestrial predators with about 7,000 described species in over 900 genera and 25 subfamilies; it is considered one of the three most abundant in a number of species within the Heteroptera (Forero 2008; Henry 2009). Putchkov and Putchkov (1985) and Maldonado (1990) published catalogs of the species. For the Neotropical Region, over 200 genera and about 1,400 species included in 21 subfamilies are recorded (Forero 2004, and personal communication to JG). 
Reduviids show a great morphological diversity with a range in size that varies from few millimeters to very large insects (Schuh and Slater 1995). Excluding the Triatominae that feed on vertebrate blood, all others live on preying.

The most common species belong to the following subfamilies: Chryxinae, Ectrichodiinae (the most abundant in the genus Brontostoma Kirkaldy), Elasmodeminae (exclusively from the neotropics, living under tree bark), Emesinae, Hammacerinae, Harpactorinae (with the most speciose genus Apiomerus Hahn and the common Arilus Hahn and Zelus (F.)), Peiratinae, Phymatinae, Reduviinae (which include the most studied genus, at least in Brazil, Zelurus Hahn), Saicinae, Sphaeridopinae, and Stenopodaine (Grazia and Fernandes 2012).

\section{Hematophagous Bugs (Reduviidae, Triatominae)}

The Triatominae are blood-sucking bugs known in Portuguese as "barbeiros." This subfamily includes about 140 species within 15 genera and five tribes. The actual taxonomic status of this subfamily that recognizes five tribes is based mainly on the revision by Lent and Wygodzinsky (1979), the most important systematic study of the group. This study has been updated by several other inclusions of new taxa (Carcavallo et al. 1998/1999; Schofield and Galvão 2009; see also Chap. 13).

These bugs are fairly big, in general from 20 to $28 \mathrm{~mm}$ length in body size, although some species may have about $5 \mathrm{~mm}$ or can reach over $40 \mathrm{~mm}$; body color is mainly brownish black with spots in yellow, orange, or red (Jurberg et al. 2012). They can be found living on bird nests, underneath the bark of trees, and in crevices of various species of trees such as bromeliads, palms, and others and feeding on animals.

They are known worldwide as transmitters of the Chagas disease, caused by the flagellate Trypanosoma cruzi (Chagas), a major disease affecting human population in several regions of the world, and very important in the neotropics (see Chap. 13 for details). The most common species in the neotropics belong to the genera Panstrongylus Berg, Triatoma Laporte, and Rhodnius Stål, and they have been illustrated by Jurberg et al. (2004, 2014).

\section{Lace Bugs (Tingidae)}

The tingids, known as lace bugs, are delicate and small bugs that show outgrowth of the pronotum and forewings with lacy aspect. The family is divided into three subfamilies (Tinginae, Cantacaderinae, and Vianaidinae), all of them represented in the Neotropical Region (Schuh et al. 2006). There are around 300 genera and 2,500 species in this family, with 70 genera and 600 species in the neotropics.

Very few species have been studied in the neotropics with regard to their biology, such as Corythaica cyathicollis (Costa) (Kogan 1960) and Leptopharsa heveae Drake and Poor (Cividanes et al. 2004), both species of economic importance. The first species is pest of several solanaceous plants, and the second damages rubber 
plants. Various other genera (over 15) include species of economic importance (see details in Chap. 14). Neal and Schaefer (2000) reviewed the species of economic importance of the world.

\subsubsection{Pentatomomorpha}

A variable number of superfamilies have been recognized within the infraorder Pentatomomorpha, with five currently accepted: Aradoidea, Coreoidea, Lygaeoidea, Pentatomoidea, and Pyrrhocoroidea (see details in Chap. 3). In this book, we will discuss in details the families most important of this infraorder, as follows.

\section{Flat Bugs (Aradidae)}

These bugs, commonly known as "flat bugs" or "bark bugs," encompass a great number of species worldwide, with over 200 genera and about 1,800 species included in eight subfamilies (Schuh and Slater 1995). For the Neotropical Region, there are 80 genera and 509 species (Coscarón and Contreras 2012).

Aradids are small to medium in length. Many tropical species are wingless and the dorsal surface appears granular or rugose. They have the mouth stylets extremely elongated and coiled; they feed on juices of fungi (mycetophagous) and also can feed on phloem, cambium, and xylem of living trees. Some species might be associated with termites and occasionally can live on bird nests. Detailed information on their biology and ecology and a list of species from the Neotropical Region and their geographical distribution are presented in Chap. 15.

\section{Lygaeoidea Families (Berytidae, Colobathristidae, Lygaeidae, and Piesmatidae)}

The Lygaeoidea is the second largest superfamily in the infraorder Pentatomomorpha, with about 700 genera and more than 4,200 species in the world. In the neotropics, there are about 184 genera and 836 species (see Chap. 16). Sweet (2000) made a comprehensive world review of the Lygaeoidea, stating their distribution, life history, biology, and damage and control of the major and minor species of economic importance.

\section{Berytidae}

The so-called stilt bugs have a slender elongated body, with long antennae and legs, measuring 2.5-11 mm, dull yellowish or reddish brown; two subfamilies are recognized: Berytinae and Metacanthinae (Schuh and Slater 1995). Berytids are 
phytophagous, being polyphagous on several species of plants of different families; however, they do have strong predatory tendencies (Henry 2000); he reviewed the most important species of the world, considering their importance either as pests, predators, or pollinators. In Brazil there are over 20 species according to the literature (Grazia and Fernandes 2012).

\section{Colobathristidae}

These bugs, elongated with slender legs, 6-20 mm long, feed exclusively on grasses, are well represented in the Neotropical Region; it is divided in two subfamilies, Colobathristinae and Dayakiellinae (Schuh and Slater 1995). In Brazil, there are 13 species (Grazia and Fernandes 2012).

\section{Lygaeidae}

These bugs known as "seed bugs," 1.2-12 mm long, are variable in shape and color, brown or black, showing aposematic coloration (red or yellow). Baranowski and Slater (2005) provided the key for the 10 subfamilies, the most important being Lygaeinae, Blissinae, Geocorinae, and Rhyparochrominae. In Brazil, 120 species and 58 genera are registered (Grazia and Fernandes 2012).

Sweet (2000) in his world review of the major and minor species of economic importance pointed out the main pest species, which belong to the following genera: Blissus, Cavalerius, Spilostethus, Nysius, Oxycarenus, Chauliops, and Elasmolomus. Of these, species of Nysius and Elasmolomus (pest of peanuts probably introduced) are of economic concern in the neotropics (see Chap. 16).

\section{Piesmatidae}

Called the ash-gray leaf bugs, the piesmatids are small $(<5 \mathrm{~mm})$ bugs. Very little is known about these bugs in the neotropics, with about only five species recorded for Brazil (Grazia and Fernandes 2012). Narisu (2000) reviews the world species of economic importance, referring to species of Piesma as transmitters of virus to sugar beet.

\section{Cotton Stainers (Pyrrhocoridae) and Bordered Plant Bugs (Largidae)}

The cotton stainers (pyrrhocorids) are medium to large bugs, frequently red or yellow and black. About 30 genera and 300 species are known. They occur in all zoogeographic regions, mostly in tropical and subtropical areas (Schuh and Slater 1995). They feed on fruits and seeds, mostly on Malvales plants. Schaefer and Ahmad (2000) made a world review of the species of economic importance, 
particularly of those in the genus Dysdercus, which include at least 17 species, of which Dysdercus peruvianus Guérin-Méneville, D. maurus Distant, and D. ruficollis (L.) are major pests in the neotropics.

The bordered plant bugs (largids), commonly colored bugs, medium to big size, are divided into two subfamilies, Physopeltinae and Larginae. A key to the subfamilies and tribes of Largidae for New and Old World is presented in Chap. 17. They feed on seeds and on plant extracts. Several species mimic ants. About 60 species included in seven genera were described from South America (Grazia and Fernandes 2012).

\section{Broad-Headed Bugs (Alydidae)}

The broad-headed bugs (alydids) are small to medium, slender, with a triangular head. They are divided into two subfamilies, Alydinae and Micrelytrinae, each divided into two tribes, Daclerini and Alydini and Micrelytrini and Leptocorisini, respectively. A key for the two subfamilies, including the tribes for the last presented by Schaefer (2004), is included in Chap. 18, with slight modifications.

The family Alydidae has over 50 genera with about 250 species; in the neotropics there are over 20 genera. The most common species belong to the genera Neomegalotomus Schaffner and Schaefer, Hyalymenus Amyot \& Serville, Stenocoris Burmeister, Cydamus Stål, and Trachelium Herrich-Schäffer (see Chap. 18). The most studied species in the neotropics is the alydine Neomegalotomus parvus (Westwood), usually associated with legumes, and may be a pest of soybean. The alydids of economic importance in the world were reviewed by Panizzi et al. (2000b).

\section{Leaf-Footed Bugs (Coreidae)}

The coreids, known as leaf-footed bugs or squash bugs, are, in general, medium to very large, strong robust bugs and may be strikingly colorful, showing expansion of femora, tibiae, humeral angles, or antennae. They are distributed worldwide, but are more abundant in the tropics.

The New World Coreidae catalog lists 158 genera with species from the neotropics (Packauskas 2010). The keys to the subfamilies of the Neotropical Region coreids are presented in Chap. 19, adapted from Packauskas (1994). These include the three subfamilies, Pseudophloeinae, Meropachyinae, and Coreinae.

Coreids are polyphagous plant feeders on gymnosperms and angiosperms, monocots and dicots. However, dicots are far more common and few coreid species are exclusively gymnosperms feeders (Schaefer and Mitchell 1983). Mitchell (2000) reviewed the coreids of economic importance of the world. In the neotropics, the most common species include Crinocerus sanctus (F.), Anisoscelis foliaceus (F.), Holhymenia histrio (F.), Leptoglossus gonagra (F.), Leptoglossus zonatus (Dallas), Phthia picta (Drury), Anasa tristis (De Geer), and Spartocera dentiventris Berg (see details in Chap. 19). 


\section{Scentless Plant Bugs (Rhopalidae)}

Rhopalidae are plant feeders bugs, mostly associated with reproductive tissues and seeds. The rhopalids are divided into two subfamilies, Rhopalinae and Serinethinae, with about 200 species in over 20 genera (Henry 1988, 2009). Its taxonomy has been studied over time by several authors (e.g., Schaefer 1965; Chopra 1967) and a world catalog was published (Göllner-Scheiding 1983). Several specific catalogs were produced for particular areas of the neotropics (e.g., Froeschner 1981, 1985, 1999; Maes and Göllner-Scheiding 1993; Pall and Coscarón 2012).

Rhopalids are small to medium and have a narrow body that resembles coreids, with brown dull coloration. They are called "scentless" plant bugs, which is an inappropriate name, since they have scent glands that produce volatile compounds (Aldrich et al. 1990).

In the neotropics, the Serinethinae of the genus Jadera are the most common species, although little studied regarding their biology and ecology. For example, for Brazil, there are nine species belonging to this genus (Grazia and Fernandes 2012). The species Jadera choprai Göllner-Scheiding is an exception, and its biology and its association with the balloon vine, Cardiospermum halicacabum L. (Sapindaceae), a weed plant in soybean fields in southern Brazil, have been investigated in detail (Panizzi and Hirose 2002; Panizzi et al. 2002, 2005).

Rhopalids, despite their wide distribution and occurrence in natural vegetation and on cultivated plants, are in general overseen and their role in these habitats is underestimated.

\section{Burrower Bugs (Cydnidae)}

The cydnids, called burrower bugs, are small- to median-sized ovoid bugs, black or brown, with flattened head and legs with strong and long spines; tibia and tarsi are modified in species with fossorial habitats that feed on roots. Some cydnids live above ground on vegetation, feeding on falling seeds or plant tissues (Schuh and Slater 1995; Schaefer 2009).

Cydnids are worldwide distributed, being well represented in tropical and temperate regions (Lis 1999, 2002). It includes more than 750 species in 93 genera and is divided into six subfamilies (Grazia et al. 2008). The cydnids in the neotropics are poorly known; Froeschner (1981) presented a key to the subfamily Cydninae of South America, the biggest and more diverse with 90 genera and 300 species.

Lis et al. (2000) made a review of the species of economic importance of the world. In the neotropics, the most common species are Scaptocoris carvalhoi Becker, Scaptocoris castanea Perty, Cyrtomenus bergi Froeschner, and Pangaeus bilineatus (Say) (see Chap. 21). 


\section{Stink Bugs (Pentatomidae)}

The pentatomids, called stink bugs, are in general broad and ovoid, 4-20 mm in length, the fourth largest family in Heteroptera, with about 800 genera and 4,700 species in the world; in the neotropics about 230 genera and 1,400 species are included in seven subfamilies of the world's nine subfamilies (Schuh and Slater 1995; see Chap. 22).

Species in the subfamily Asopinae are predacious and are important as biological control agents. The most common species in the neotropics include those in the genera Alcaeorrhynchus Bergroth, Apateticus Dallas, Euthyrhynchus Dallas, Brontocoris Thomas, Perillus Stål, Podisus Herrich-Schäffer, Stiretrus Laporte, Supputius Distant, and Tylospilus Stål. Two species, Podisus maculiventris (Say) and Podisus nigrispinus (Dallas), show potential in biological control programs (De Clercq 2000).

The exclusively Neotropical subfamily Cyrtocorinae is small with four genera and 11 species (Packauskas and Schaefer 1998); they are cryptically colored black to brown and are small to medium. Cyrtocorines are rare and of minor economic importance and little is known about their biology. Nymphs and adults of Cyrtocoris egeris Packauskas \& Schaefer were observed feeding on immature soybean pods in Argentina (Schaefer et al. 2005).

The subfamily Discocephalinae includes two tribes, Discocephalini and Ochlerini, with more than 70 genera and over 300 species; almost all are medium sized and dark colored and restricted to the neotropics. The most known species of Discocephalini belong to the genus Antiteuchus Dallas, and in Ochlerini, the genera Lincus Stål and Macropygium Spinola include species of economic importance by vectoring Phytomonas spp. (Trypanosomatidae) in palms in South America (see details in Chap. 22).

The subfamily Edessinae is one of the largest with about 300 species (da Silva et al. 2013) distributed mostly in the Neotropical Region. It includes colored and large stink bugs. They feed on plants and may show economic importance, such as Edessa meditabunda (F.), particularly on soybean and on tobacco, and Edessa rufomarginata (De Geer) that feeds on Leguminosae and on Solanaceae causing damage to tomato and potato (Panizzi et al. 2000a).

The subfamily Pentatominae is the most diverse with an estimated number between 400 to 600 genera and 2,700 to 3,300 species; the exact number of groups (tribes, genera, and species) is uncertain because the definition of the subfamily is still under discussion (Rider 2013).

They are all phytophagous and many species are economically important as pests of cultivated crops. Main species include Nezara viridula (L.), Piezodorus guildinii (Westwood), and Euschistus heros (F.) and species of Arvelius Spinola, Loxa Amyot \& Serville, Agroecus Dallas, Dichelops Spinola, and Chinavia Orian as important pests of soybean and other crops, and Mormidea v-luteum (Lichtenstein), Oebalus poecilus (Dallas), Oebalus ypsilongriseus (De Geer), and Tibraca limbativentris Stål may cause damage to rice and wheat (Panizzi et al. 2000a). Pentatominae are, 
in general, highly polyphagous, and their life history includes several host plant sequences (Panizzi 1997).

The subfamilies Podopinae and Stirotarsinae are represented by only one species each in the Neotropical Region.

The review of stink bugs of economic importance in the world was carried out by Panizzi et al. (2000a).

\section{Shield Bugs (Scutelleridae)}

The scutellerids are known as shield bugs or, sometimes, jewel bugs. These common names are based on their enlarged scutellum that covers the abdomen and their striking vivid color, with body length 5-20 mm long (Schuh and Slater 1995). These bugs are included in 80 genera and about 500 species worldwide (Tsai et al. 2011). In the neotropics, 25 genera and 112 species are registered, although these numbers are much probably underestimated (see Chap. 23).

Scutellerids are included in eight subfamilies, of which three occur in the neotropics, Pachycorinae with 23 genera and Scutellerinae and Elvisurinae with one genus each. The most common species in the neotropics are Pachycoris torridus (Scopoli), Pachycoris klugii Burmeister, Augocoris illustris (F.), Augocoris gomesii Burmeister, Agonosoma flavolineata (Laporte), Agonosoma trivittata (Panzer), Symphylus deplanatus (Herrich-Schaeffer), and Tetyra pinguis Germar (see details in Chap. 23).

Shield bugs are phytophagous feeding on an array of plants, but they might be necrophagous and be attracted to carrion. Javahery et al. (2000) reviewed the species of economic importance of the world.

\section{Negro Bugs (Thyreocoridae)}

The so-called negro bugs, Thyreocoridae Amyot \& Serville (Corimelaenidae Uhler), include two subfamilies, Thyreocorinae and Corimelaeninae, this last represented in the Neotropical Region. They are relatively small and dark colored, with oval-elongated body and large scutellum (Grazia and Fernandes 2012). Galgupha Amyot \& Serville is the most diverse Neotropical genus with 155 species in 15 subgenera; about 160 species are recorded in the neotropics, their biology poorly known (see Chap. 24).

Negro bugs are phytophagous feeding on flowers and on developing or ripe fruits. Despite their occurrence on many crops, they are regarded as minor pests on orchards and flowers and are not mentioned among the Heteroptera of economic importance (Schaefer and Panizzi 2000). 


\section{Pentatomoid Families (Acanthosomatidae, Canopidae, Dinidoridae, Megarididae, Phloeidae, and Tessaratomidae)}

These are pentatomoid bugs that belong to small families, which include less than 70 species in less than 30 genera in the neotropics; species may show maternal care and have cryptic coloration; despite information on their taxonomic status, and on their biology and ecology, in general, they are poorly studied (see Chap. 25).

\section{Acanthosomatidae}

These are medium to large bugs, distributed mainly in temperate regions or at high altitudes in the subtropics. They are phytophagous, and some species show maternal care (Tallamy and Schaefer 1997). Few Neotropical species had their biology studied (Faúndez and Osorio 2010a, b). No acanthosomatids with economic importance are recorded from the neotropics (Schaefer et al. 2000).

\section{Canopidae}

Exclusively distributed in the neotropics, canopids are small- to medium-sized bugs and are shiny black. Due to their appearance, they are usually mistaken as coleopterans. Eight known species belong to the genus Canopus F. Their biology and ecology are less known. They feed on fungi (McHugh 1994).

\section{Dinidoridae}

Dinidorids are large, aposematic colored bugs, brown or black with red/yellow stripes, and included in two subfamilies Dinidorinae and Megymeninae, mostly distributed in the Afrotropical and Oriental regions. In the neotropics, only the genus Dinidor Latreille is recorded, with six species distributed in South America (see Chap. 25).

Species studied are phytophagous and polyphagous. Schaefer et al. (2000) reviewed the species of economic importance; none were referred to from the neotropics. Few data are available on their biology and ecology in the neotropics; Dinidor mactabilis (Dinidorinae) was recorded on Smilax japecanga Grisebach (Smilacaceae) in southern Brazil, which deposit large number of eggs in clusters on branches of the host plant (Grazia and Fernandes 2012).

\section{Megarididae}

These are small, dark, and shiny bugs and have ovoid and convex shape. They are distributed exclusively in the neotropics, in which 16 extant species are known all in the genus Megaris Stål. They are considered phytophagous and their biology and ecology are mostly unknown (see Chap. 25 for more details). 


\section{Phloeidae}

The phloeids are large, flat depressed bugs with global expansions around the body which makes them look peculiar; they form colonies on the tree trunks where they live, being strongly mimetic (Grazia and Fernandes 2012). They are distributed mostly in the Neotropical Region, with four species in three genera: one species in the genus Serbana Distant, which occurs only in Borneo (Leston 1953), two species in Phloea Spinola, and one species in Phloeophana Leston, the latter two restricted to Brazil (Lent and Jurberg 1965).

\section{Tessaratomidae}

Tessaratomids are robust, ovoid-elongated, medium to large bugs; Neotropical species are in general dark green; they are mostly distributed in the Old World tropics with over 40 genera and over 200 species worldwide; the genus Piezosternum Amyot \& Serville has worldwide distribution and includes three endemic species to the neotropics (see Chap. 25).

The biology and ecology of tessaratomids were studied in the Old World, and few data are available from the neotropics. They are polyphagous on plants; the Neotropical species Piezosternum subulatum (Thunberg) was recorded on some cultivated plants in Nicaragua (Maes 1994). However, there are no records on species causing economic damage in the neotropics; the bronze orange bug, Musgraveia sulciventris Stål, is referred to as a pest of citrus in the Australian region (Schaefer et al. 2000).

\subsection{Concluding Remarks}

Heteropterans are indeed a diverse and complex group of insects. They live on several different habitats (terrestrial, aquatic, intertidal and in association with other insects and spiders) as phytophagous (from seed, fruit, leaf, root to mycelia of fungi feeding), or as carnivorous (predators on other insects and arthropods and even feeding on blood of vertebrates); they have great ability to disperse and to adapt to different habitats through mimicry and protective coloration and shape (Schuh and Slater 1995). As a consequence of their success, the clash with humans' interests is inevitable, and many species of heteropterans became with time of economic and/or medical concern. Efforts are focused on research to better understand their biology and ecology in order to develop control strategies to manage pest species to crops or others of medical importance (Schaefer and Panizzi 2000).

Despite the many years of research, heteropterans in the Neotropical Region are still poorly known, as the readers of this book will rapidly verify. However, we hope that the information provided by each chapter will facilitate to learn the knowledge we actually have on the fauna of the heteropterans of the neotropics. 


\section{References}

Aldrich JR, Carroll SP, Oliver JE, Lusby WR, Rudmann AA, Waters RM (1990) Exocrine secretions of scentless plant bugs; Jadera, Boisea, Niesthrea species (Hemiptera: Heteroptera: Rhopalidae). Biochem Syst Ecol 18:369-376

Andersen NM (1977) A new and primitive genus and species of Hydrometridae (Hemiptera, Gerromorpha) with a cladistic analysis of relationships within the family. Entomol Scand 8:301-316

Andersen NM (1981) Semiaquatic bugs: phylogeny and classification of the Hebridae (Heteroptera: Gerromorpha) with revisions of Timasius, Neotimasius and Hyrcanus. Syst Entomol 6:377-412

Andersen NM (1982) The semiaquatic bugs (Hemiptera, Gerromorpha). Phylogeny, adaptations, biogeography and classification. Entomonograph 3:1-455

Baranowski RM, Slater JA (2005) The Lygaeidae of the West Indies, Florida Agric Experiment Station. Bull 402. Agricultural Experiment Station, Gainesville, pp 1-266

Berg C (1879) Hemiptera Argentina enumeravit speciesque novas. Pauli E.Coni, Bonariae

Carcavallo RU, Galíndez-Girón I, Jurberg J, Lent H (eds) (1998/1999) Atlas of Chagas disease vectors in the Americas. Editora Fiocruz, Rio de Janeiro

Carpintero DL (2002) Catalogue of the Neotropical Anthocoridae (Heteroptera). Rev Soc Entomol Arg 61:25-44

Chopra NP (1967) The higher classification of the family Rhopalidae (Hemiptera). Trans R Entomol Soc Lond 119:363-399

Cividanes FJ, Fonseca FS, Santos TM (2004) Distribuição de Leptopharsa heveae em seringal no Estado de São Paulo. Pesq Agropec Brasil 39:1053-1056

Cobben RH (1978) Evolutionary trends in Heteroptera, Part II. Mouthpart-structures and feeding strategies. Centre for Agricultural Publishing and Documentation, Wageningen

Coscarón MC, Contreras EF (2012) Catalog of Aradidae (Hemiptera: Heteroptera) for the Neotropical Region. Zootaxa 3466:1-103

Costa Lima AM (1940) Insetos do Brasil. Hemipteros. Tomo II. Escola Nacional de Agronomia, Rio de Janeiro

da Silva VJ, Nunes DM, Fernandes JAM (2013) Paraedessa, a new genus of Edessinae (Hemiptera: Heteroptera: Pentatomidae. Zootaxa 3716:395-416

De Clercq P (2000) Predaceous stinkbugs (Pentatomidae: Asopinae). In: Schaefer CW, Panizzi AR (eds) Heteroptera of economic importance. CRC Press, Boca Raton, pp 737-789

Faúndez EI, Osorio GA (2010a) Contribution to the knowledge of Cylindrocnema plana Mayr, 1864 (Hemiptera: Heteroptera: Acanthosomatidae). An Ins Patagonia 38:159-161

Faúndez EI, Osorio GA (2010b) New data on the biology of Sinopla perpunctatus Signoret, 1864 (Hemiptera: Heteroptera: Acanthosomatidae). Bol Biodiversidad Chile 3:24-31

Forero D (2004) Diagnosis de los géneros neotropicales de la família Reduviidae (Hemiptera: Heteroptera), y su distribución en Colombia (excepto Harpactorinae). In: Fernández F, Andrade G, Amat G (eds) Insectos de Colombia, vol 3. Academia Colombiana de Ciencias Exactas, Físicas y Naturales, Bogotá, pp 128-275

Forero D (2008) The systematics of the Hemiptera. Rev Colomb Entomol 34:1-21

Froeschner RC (1981) Heteroptera or true bugs of Ecuador: a partial catalog. Smithsonian Contrib Zool 322:1-147

Froeschner RC (1985) Synopsis of the Heteroptera or true bugs of the Galápagos Islands. Smithson Contrib Zool 407:39-40

Froeschner RC (1999) True bugs (Heteroptera) of Panama: a synoptic catalog as a contribution to the study of Panamanian biodiversity. Am Entomol Inst 61:1-393

Göllner-Scheiding U (1983) General-kataloge der Familie Rhopalidae (Heteroptera). Mitt Zool Mus Berlin 59:37-189

Grazia J, Fernandes JAM (2012) Subordem Heteroptera Linnaeus, 1758. In: Rafael JA, Melo GAR, Carvalho CJKB, Casari AS, Constantino R (eds) Insetos do Brasil. Diversidade e Taxonomia. Ed. Holos, Ribeirão Preto, pp 369-405 
Grazia J, Schuh RT, Wheeler WC (2008) Phylogenetic relationships of family groups in Pentatomoidea based on morphology and DNA sequences (Insecta: Heteroptera). Cladistics 24:932-976

Harris HM (1930) Notes on some South American Nabidae, with descriptions of new species (Hemiptera). Ann Carnegie Mus 19:241-248

Harris HM (1931) Nabidae from the state of Paraná. Ann Mus Zool Polonici 9:179-185

Harris HM (1939) Miscelánea sobre Nabidae sudamericanos (Hemiptera). Not Mus La Plata 4:367-377

Henry TJ (1988) Family Rhopalidae Amyot and Serville, 1843. In: Henry TJ, Froeschner RC (eds) Catalog of the Heteroptera, or true bugs, of Canada and the continental United States. Brill, Leiden, pp 652-664

Henry TJ (2000) Stilt bugs (Berytidae). In: Schaefer CW, Panizzi AR (eds) Heteroptera of economic importance. CRC Press, Boca Raton, pp 725-735

Henry TJ (2009) Biodiversity of Heteroptera. In: Foottit RG, Adler PH (eds) Insect biodiversity: science and society. Blackwell Publishing Ltd., Oxford, pp 223-263

Javahery M, Schaefer CW, Lattin JD (2000) Shield bugs (Scutelleridae). In: Schaefer CW, Panizzi AR (eds) Heteroptera of economic importance. CRC Press, Boca Raton, pp 475-503

Jurberg J, Galvão C, Noireau F, Carcavallo RU, Rocha DS, Lent H (2004) Uma iconografia dos triatomíneos. Entomol Vect 11:457-494

Jurberg J, Galvão C, Rocha DS, Dale C, Cunha V (2012) Vetores da doença de Chagas no Brasil. Instituto Oswaldo Cruz, Rio de Janeiro

Jurberg J, Rodrigues JMS, Moreira FFF, Dale C, Cordeiro IRS, Lamas VD Jr, Galvão C, Rocha DS (2014) Atlas iconográfico dos triatomíneos do Brasil (Vetores da doença de Chagas no Brasil). Instituto Oswaldo Cruz, Rio de Janeiro

Kerzhner IM (1986) Neotropical Nabidae (Heteroptera), 1: A new genus, some new species, and notes on synonymy. J NY Entomol Soc 94:180-193

Kogan M (1960) Corythaica cyathicollis (Costa, 1864), aspectos sistemáticos, biológicos e econômicos (Hemiptera, Tingidae). Mem Instituto Oswaldo Cruz 58:59-88

Lattin JD (2000) Minute pirate bugs (Anthocoridae). In: Schaefer CW, Panizzi AR (eds) Heteroptera of economic importance. CRC Press, Boca Raton, pp 607-637

Lent H, Jurberg J (1965) Contribuição ao conhecimento dos Phloeidae Dallas, 1851, com um estudo sôbre genitália (Hemiptera, Pentatomoidea). Rev Bras Biol 25:123-144

Lent H, Wygodzinsky P (1979) Revision of Triatominae (Hemiptera, Reduviidae) and their significance as vectors of Chagas disease. Bull Am Mus Nat Hist 163:123-529

Leston D (1953) "Phloeidae" Dallas: systematics and morphology, with remarks on the phylogeny of "Pentatomoidea" leach and upon the position of "Serbana" distant (Hemiptera). Rev Bras Biol 13:121-140

Lis JA (1999) Burrower bugs of the Old World - a catalogue (Hemiptera: Heteroptera: Cydnidae). Genus 10:165-249

Lis JA (2002) Burrower bugs described after the Old World catalogue of the family (Hemiptera: Heteroptera: Cydnidae). Pol Pis Entomol 71:7-17

Lis JA, Becker M, Schaefer CW (2000) Burrower bus (Cydnidae). In: Schaefer CW, Panizzi AR (eds) Heteroptera of economic importance. CRC Press, Boca Raton, pp 405-419

Maes J-M (1994) Catálogo de los Pentatomoidea (Heteroptera) de Nicaragua. Rev Nicar Entomol 28:1-29

Maes PJ, Göllner-Scheiding U (1993) Catálogo de los Coreoidea (Heteroptera). Rev Nica Entomol 25:1-19

Maldonado CJ (1990) Systematic catalogue of the Reduviidae of the world. Carib J Sci Spec Publ $1: 1-694$

McHugh JV (1994) On the natural history of Canopidae (Heteroptera: Pentatomoidae). J New York Entomol Soc 102:112-114

Mitchell PL (2000) Leaf-footed bugs. In: Schaefer CW, Panizzi AR (eds) Heteroptera of economic importance. CRC Press, Boca Raton, pp 337-403 
Narisu (2000) Ash-gray leaf bugs (Piesmatidae). In: Schaefer CW, Panizzi AR (eds) Heteroptera of economic importance. CRC Press, Boca Raton, pp 265-270

Neal JW Jr, Schaefer CW (2000) Lace bugs (Tingidae). In: Schaefer CW, Panizzi AR (eds) Heteroptera of economic importance. CRC Press, Boca Raton, pp 85-137

Packauskas RJ (1994) Key to the subfamilies and tribes of the New World Coreidae (Hemiptera) with a checklist of published keys to genera and species. Proc Entomol Soc Wash 96:44-53

Packauskas R (2010) Catalog of the Coreidae, or leaf-footed bugs, of the new world. Fort Hays Stud 5:1-270

Packauskas RJ, Schaefer CW (1998) Revision of the Cyrtocoridae (Hemiptera: Pentatomoidea). Ann Entomol Soc Am 91:363-386

Pall JL, Coscarón MC (2012) The Rhopalidae (Hemiptera: Heteroptera) of Argentina. J Nat Hist 46:1441-1465

Panizzi AR (1997) Wild hosts of pentatomids: ecological significance and role in their pest status on crops. Annu Rev Entomol 42:99-122

Panizzi AR, Hirose E (2002) Seed-carrying and feeding behavior of Jadera choprai GöllnerScheiding (Heteroptera: Rhopalidae). Neotrop Entomol 31:327-329

Panizzi AR, McPherson JE, James DG, Javahery M, McPherson RM (2000a) Stink bugs (Pentatomidae). In: Schaefer CW, Panizzi AR (eds) Heteroptera of economic importance. CRC Press, Boca Raton, pp 421-474

Panizzi AR, Schaefer CW, Natuhara Y (2000b) Broad-headed bugs (Alydidae). In: Schaefer CW, Panizzi AR (eds) Heteroptera of economic importance. CRC Press, Boca Raton, pp 321-336

Panizzi AR, Hirose E, Chocorosqui VR (2002) Unusual oviposition behavior by a seed feeding bug (Heteroptera: Rhopalidae). Neotrop Entomol 31:477-479

Panizzi AR, Schaefer CW, Hirose E (2005) Biology and descriptions of nymphal and adult Jadera choprai (Hemiptera: Rhopalidae). Ann Entomol Soc Am 98:515-526

Pereira DLV, de Melo AL, Hamada N (2007) Chaves para identificação para famílias e gêneros de Gerromorpha e nepomorpha (Insecta: Heteroptera) na Amazônia central. Neotrop Entomol 36:210-228

Putchkov VG, Putchkov PV (1985) A catalog of assassin-bugs genera of the world (Heteroptera: Reduviidae). Published by Authors, Kiev

Rider DA (2013) Pentatomoidea home page. North Dakota State University, Fargo

Schaefer CW (1965) The morphology and higher classification of the Coreoidea (HemipteraHeteroptera). Part III. The families Rhopalidae, Alydidae, and Coreidae. Misc Publ Entomol Soc Am 5:1-76

Schaefer CW (2004) Key to the genera of New World Alydidae (Hemiptera: Heteroptera). Proc Entomol Soc Wash 106:280-287

Schaefer CW (2009) Prosorrhyncha (Heteroptera and Coleorrhyncha). In: Resh VH, Cardé RT (eds) Encyclopedia of insects, 2nd edn. Academic, Amsterdan, pp 839-855

Schaefer CW, Mitchell PL (1983) Food plants of the Coreoidea (Hemiptera: Heteroptera). Ann Entomol Soc Am 76:591-615

Schaefer CW, Ahmad I (2000) Cotton strainers and their relatives (Pyrrhocoroidea: Pyrrhocoridae and Largidae). In: Schaefer CW, Panizzi AR (eds) Heteroptera of economic importance. CRC Press, Boca Raton, pp 271-308

Schaefer CW, Panizzi AR (2000) Heteroptera of economic importance. CRC Press, Boca Raton

Schaefer CW, Panizzi AR, James DG (2000) Several small pentatomoid families (Cyrtocoridae, Dinidoridae, Eurostylidae, Plataspidae, and Tessaratomidae). In: Schaefer CW, Panizzi AR (eds) Heteroptera of economic importance. CRC Press, Boca Raton, pp 505-512

Schaefer CW, Panizzi AR, Coscarón MC (2005) New records of plants fed upon by the uncommon heteropterans Cyrtocoris egeris Packauskas \& Schaefer and C. trigonus (Germar) (Hemiptera: Cyrtocoridae) in South America. Neotrop Entomol 34:127-129

Schofield CJ, Galvão C (2009) Classification, evolution and species groups within the Triatominae. Acta Trop 110:88-100 
Schuh RT (1979) Evolutionary trends in Heteroptera. Part II. Mouthpart-structures and feeding strategies. Syst Zool 28:653-656

Schuh RT, Slater JA (1995) True bugs of the world (Hemiptera: Heteroptera). Classification and natural history. Cornell University Press, Ithaca

Schuh RT, Štys P (1991) Phylogenetic analysis of Cimicomorphan family relationships (Heteroptera). J NY Entomol Soc 99:298-350

Schuh RT, Galil B, Polhemus JT (1987) Catalog and bibliography of Leptopodomorpha (Heteroptera). Bull Am Mus Nat Hist 185:243-406

Schuh RT, Cassis G, Guilbert É (2006) Description of the first recent macropterous species of Vianaidinae (Heteroptera: Tingidae) with comments on the phylogenetic relationships of the family within the Cimicomorpha. J NY Entomol Soc 114:38-53

Sweet MH II (2000) Seed and chinch bugs (Lygaeoidea). In: Schaefer CW, Panizzi AR (eds) Heteroptera of economic importance. CRC Press, Boca Raton, pp 143-264

Tallamy DW, Schaefer CW (1997) Maternal care in the Hemiptera: ancestry, alternatives, and current adaptive value. In: Choe JC, Crespi BJ (eds) The evolution of social behavior in insects and arachnids. Cambridge University Press, Cambridge/New York, pp 94-115

Tsai J-F, Rédei D, Yeh GF, Yang MM (2011) Jewel bugs of Taiwan (Heteroptera: Scutelleridae). National Chung Hsing University, Taichung

Weirauch C, Schuh RT (2011) Systematics and evolution of Heteroptera: 25 years of progress. Annu Rev Entomol 56:487-510

Weirauch C, Štys P (2014) Litter bugs exposed: phylogenetic relationships of Dipsocoromorpha (Hemiptera: Heteroptera) based on molecular data. Insect Syst Evol 45:1-20

Wheeler AG (2000a) Plant bugs (Miridae) as plant pests. In: Schaefer CW, Panizzi AR (eds) Heteroptera of economic importance. CRC Press, Boca Raton, pp 37-83

Wheeler AG (2000b) Predacious plant bugs (Miridae). In: Schaefer CW, Panizzi AR (eds) Heteroptera of economic importance. CRC Press, Boca Raton, pp 657-693

Wheeler AG (2001) Biology of the plant bugs (Hemiptera: Miridae). Pests, predators, opportunists. Cornell University Press, Ithaca

Wygodzinsky PW, Schmidt K (1991) Revision of the New World Enicocephalomorpha (Heteroptera). Bull Am Mus Nat Hist 200:1-265 